\title{
Analysis of Health Risk Factors in the Vegetable Production Chain in the City of N'Djamena-Chad
}

\author{
Nazal Alhadj Markhous ${ }^{1}$, Abdelsalam Tidjani ${ }^{3}$, Abdelsalam Adoum Doutoum ${ }^{2}$, Djamalladine M. Doungous ${ }^{2}$, \\ Ibrahim Amoukou ${ }^{4} \&$ Balla Abdourahamane ${ }^{4}$ \\ ${ }^{1}$ University of Sarh, Chad \\ ${ }^{2}$ National Higher Institute of Science and Technology of Abeche, Chad \\ ${ }^{3}$ University of N'Djamena, Chad \\ ${ }^{4}$ Abdou Moumouni University of Niamey, Niger \\ Correspondence: Abdelsalam Tidjani, Faculty of Human Health Sciences, University of N'Djamena, BP 1117 \\ N’Djamena, Chad. E-mail: abdelti@yahoo.fr
}

Received: March 15, 2019 Accepted: April 4, 2019 Online Published: May 10, 2019

doi:10.5539/jfr.v8n3p111

URL: https://doi.org/10.5539/jfr.v8n3p111

\begin{abstract}
Several market gardeners have settled in the city and supply urban markets with fresh vegetables throughout the year. Despite their nutritional importance, market gardening products may carry health risks. The objective of this study is to identify and analyse the potential risk factors that could lead to the appearance of microbiological and physicochemical hazards in the production chain of fresh vegetables from these market gardening operations. The work was carried out in 5 permanent market gardening sites in the city of N'Djamena (Chad, Africa) and involved 96 market gardeners surveyed. Data related to production methods were collected. Standard methods were used to carry out microbiological analysis tests on 15 samples of vegetables and fruits taken from 3 sites. The results of the survey show that urban market gardening in N'Djamena is dominated by two plant species: lettuce (Lactuca sativa) and rocket (Eruca sativa). It is geared towards the production of leafy vegetables. The health risks associated with the conditions of production are numerous and real: the proximity of roads, the use of dirty water for irrigation, the overdose of chemical fertilizers (urea) and pesticides, and finally the unhygienic harvesting and transport. The high-water content of fresh vegetables and the lack of processes for the elimination of pathogenic microorganisms also do not guarantee the sanitary quality of the vegetables produced and can thus increase the risk of foodborne infections. The results of the microbiological evaluation showed the presence of germs pathogens including Escherichia coli, Staphylococcus aureus, Aeromonas spp. and Salmonella sp. in vegetable and fruit. Therefore, the best strategy to obtain a healthy product is to educate producers on good agricultural practices including reasoned fertilization, clean water, treated wastewater, approved pesticides.
\end{abstract}

Keywords: food, market gardening, fresh vegetables, health risks, N'Djamena

\section{Introduction}

In Chad, as in many other countries, there is the practice of agriculture around cities. Urban populations, because of new lifestyles and cultural mixing, are looking for a diversification of their consumption, mainly on fresh, perishable products: vegetables, fruits, animal products (Temple \& Moustier, 2004). Although it is constituted by a variety of agricultural and pastoral activities that can take place within the limits or periphery of urban agglomerations (Smith et al., 2004), market gardening has taken an important part in this type of agriculture. Many market gardeners have settled in cities and around cities and are supplying urban markets with fresh fruits and vegetables throughout the year. This form of exploitation of the environment represents a major challenge in terms of employment, living environment, waste management and the supply of fresh produce to cities (Moustier, 1990), thus creating an important base improvement of the food and nutritional situation of urban populations in these areas. At the microeconomical level, it is an important source of income for the poorest households in urban areas (Golhor, 1995).

The city of N'Djamena in Chad, like most cities in developing countries is home of several basins of production of fresh vegetables. Market gardening has played an important role in this agriculture. Market gardening provides city dwellers with fresh vegetables, which have become almost indispensable in their daily diet (Nazal 
et al., 2017). In contrast to the seasonal production of food crops in the countryside, urban and peri-urban vegetable production is used throughout the year using intensive production techniques (irrigation, organic and mineral fertilizers, plant protection products, etc.) on small areas. As a result, this production ensures a constant supply of various vegetables to meet the demands of the urban population and, as such, contributes to food security. In addition, the activity provides regular income to producers of various origins.

However, these various assets that militate in favour of its valuation, market gardening in the city of N'Djamena, is marginalized in urban planning policies. This is why land is today a major constraint to its development. This climate of land insecurity coupled with the flooding of some production areas for a large part of the year, does not reassure producers to invest in modern and sustainable tools, leading to major changes in their farming practices. To maintain and increase their production in the face of strong consumer demand, market gardeners are forced to intensify their production, use pesticides and wastewater in some sites. The practices of this type of production system involve economic and health risks that must be prevented and controlled (UNDP, 1996). It is not uncommon also to note that certain practices of harvesting and transporting market garden products are done in unsatisfactory conditions in view of the rules of hygiene. These poor practices could introduce pathogens into the products and thereby expose consumers to a possible hazard.

Consumers expect to be protected from the risks present all along the food chain, from the primary producer to the consumer: often referred to as "from farm to table" (FAO/OMS, 2003). Therefore, our study proposes to identify and analyse all the relevant risk factors that could lead to the appearance of microbiological and physicochemical hazards on fresh vegetables from vegetable farms in urban and peri-urban areas of N'Djamena to take preventive measures to have healthy products.

\section{Methods}

This study was conducted in N'Djamena, the capital of Chad. Located in the center-west of the country, at the confluence of the rivers Chari and Logone, the city of N'Djamena, which concentrates nearly $40 \%$ of the urban population, knows a perpetual growth characterized by a strong galloping urbanization. Microbiological analyzes were carried out at the Food Sciences and Nutrition Research Laboratory (LARSAN). After an exploratory study in the study area and documentary research on market gardening systems in N'Djamena, the various market gardening sites were listed and the large sites serving the major markets were selected for considering sampling:

- Access to water: sites were selected to include different water sources;

- The importance of the site: this criterion considers the number of producers operating on the site or its importance in terms of area;

- And finally, the permanence of market gardening activities in the site.

This allowed to identify 5 vegetable production sites (figure 1) as follows: Djamba Ngato Airport (1), Djamba Ngato Base (2), Sabangali (3), Habena-Double lane (4) and finally Habena-Komé (5).

For microbiological analyzes, a total of 15 samples of vegetables and fruits were randomly collected on 3 sites, or 5 units per site. They were stored in coolers at $4{ }^{\circ} \mathrm{C}$ and transported aseptically to LARSAN Laboratory.

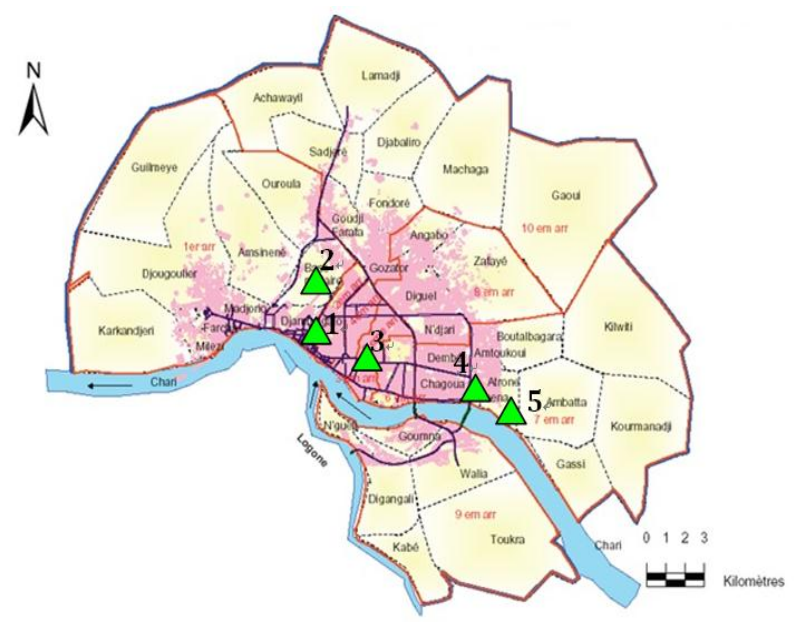

Figure 1. Location of the market gardening; zones surveyed 1. Djamba Ngato Airport; 2. Djamba Ngato Base; 3. Sabangali; 4. Habena-Double lane; 5. Habena-Komé

The microbiological evaluation was performed according to standard methods. Also supports relating to these 
standards are used (Leyral \& Vierling, 1991; AFNOR, 2002). Escherichia coli, Aeromonas spp., Staphylococcus aureus and Salmonella sp. germs were sought. Vegetable samples are taken at maturity. Samples of 5 units corresponding to a test portion of $100 \mathrm{~g}$ were made. Then, after grinding with a Blender ${ }^{\circledR}$ type mill at $1500 \mathrm{rpm}$, $10 \mathrm{~g}$ of each ground material are suspended in $90 \mathrm{ml}$ of tryptone-salt solution containing $0.03 \mathrm{~g} / 1$ of tween 80 ; then the revivification is done for $45 \mathrm{~min}$ at laboratory temperature $\left(25^{\circ} \mathrm{C}\right)$. The yellow colonies on the agar Hektoen and colonies with metallic reflections were suspicious of $E$. coli after 18 to 24 hours of incubation at $37^{\circ} \mathrm{C}$. The colonies of $S$. aureus presented yellow color on Chapman agar. Aeromonas spp. was carried out on Pril-xylose-Ampicillin (PXA) agar, clear red colonies are suspected of Aeromonas spp. For the Salmonella search, $25 \mathrm{~g}$ of sample were homogenized in $225 \mathrm{ml}$ of buffered peptone water. The identification was made by API 20E (BioMérieux, France).

Data collection is based on individual questionnaire surveys, 96 questionnaires were administered to randomly selected producers representing $40.9 \%$ of the total agricultural population listed (Table 1). The data collected focused on production techniques, input management, water use and the geographical location of this activity.

The collected data were entered on Excel XLSTAT software, processed and analyzed by descriptive statistics to determine averages and frequencies. Statistical analysis was performed using the chi-square test $\left(\chi^{2}\right)$ for comparison of two variables. Differences were considered significant when $\mathrm{P} \leq 0.05$.

Table 1. Distribution of market gardeners surveyed by production site

\begin{tabular}{lll}
\hline Site & Total number of producers surveyed & Number of producers surveyed \\
\hline Djamba Ngato Airport & 42 & 18 \\
Djamba Ngato Base & 113 & 46 \\
Sabangali & 35 & 12 \\
Habena Double line & 25 & 11 \\
Habena-Komé & 20 & 9 \\
TOTAL & 235 & 96 \\
\hline
\end{tabular}

\section{Results}

\subsection{Types of Vegetables Produced}

This study identified 11 vegetable species in the study area (Table 2). However, 2 species were identified as the main vegetables grown by market gardeners: lettuce (Lactuca sativa) and rocket (Eruca sativa). Indeed, in the various production sites studied, all market gardeners produce at least lettuce or rocket. Some produce both at the same time. Other plant species are grown at low proportions. They are grown for self-consumption or for certain expenses specific to each market. The number of species cultivated per market gardener varies from 1 to 4 . The local names of the different vegetables produced and their uses are shown in the table below (Table 2).

Table 2. Vegetables encountered in the different production perimeters

\begin{tabular}{lllll}
\hline Scientific Name & Family Name & English Name & Local Name (Local arabic) & Consumed Body \\
\hline Lactuca sativa & Asteraceae & Lettuce & Salade & Leaf \\
Eruca sativa & Brassicaceae & Rocket & Djir-djir & Leaf \\
Hibiscus sabdariffa & Malvaceae & Sorrel & Karkandji & Leaf, fruit \\
Daucus carota & Apiaceae & Carrot & Carotte & Root \\
Brassica oleracea & Brassicaceae & Cabbage & Chou & Leaf \\
Allium cepa & Liliaceae & Onion & Bassal & Bulb \\
Hibiscus esculentus & Malvaceae & Okra & Daraba & Fruit \\
Petroselinum sativum & Umbellifers & Parsley & Persil & Leaf \\
Basella alba & Basellaceae & Spinach & Épinard & Leaf \\
Apium glaveolens & Umbellifers & Celery & Céleri & Leaf \\
Capsicum annuum & Solanaceae & Green Pepper & Poivron & Fruit \\
\hline
\end{tabular}

Depending on the organs consumed (Table 2), vegetable production is oriented towards the production of leafy vegetables $(63,6 \%$ of species).

\subsection{The Geographical Location of the Production Sites}

The survey showed that the vegetable production sites in the study area are located either along the waterways (Habena-Double Lane and Habena-Komé) or in empty state areas (Djamba Ngato-Aéroport and Djamba 
Ngato-Base) or in fenced and unopened plots (Sabangali). All market gardening perimeters are located not far from the roads. The average distance between the road and crops is estimated at $30 \mathrm{~m}$ with a minimum distance of $50 \mathrm{~cm}$ at Djamba Ngato-Airport (Figure 2a) and a maximum distance of $100 \mathrm{~m}$ at Habena-Komé.

\subsection{Cultural Practices in Urban and Peri-urban N'Djamena}

Agricultural practices are considered as all the processes and ways of acting of the farmers (Milleville, 1987) implementing a technical operation. In this study carried out in the city of N'Djamena, it was limited to the analysis of agricultural practices that could have repercussions on the hygienic quality of market garden products and thus the health of the consumers, namely: crop irrigation, improving soil fertility and phytosanitary protection of plants.

\subsubsection{Crops Irrigation}

In the study area, surface waters (river), groundwater (boreholes, wells) and sewage (sewage) are the sources of water supply for market gardeners. Producers at the same production site use the same source of water. Thus, those in Habena-Komé use surface water; groundwater is used in Habena-Double lane, Sabangali and Djamba Ngato-Base, and producers in Djamba Ngato-airport use wastewater (Figure 2b). As a result, the surveys show that most of the sites $(71.9 \%)$ draw their irrigation water from the water table (borehole or open well). Sewer water is used by $18.8 \%$ of market gardeners (Figure 2b). Although the city of N'Djamena is crossed by two rivers, only $9.4 \%$ of producers irrigate with water from the river. Our survey showed that for the water supply to the plants, all growers use manual watering with a watering can (Figure 2b).

\subsubsection{Improvement of Soil Fertility}

Soil fertilization is done through organic and inorganic fertilizers. Cow dung is identified as the main source of organic matter used by $18.8 \%$ of market gardeners in vegetable production. This organic fertilizer is brought once at the beginning of the cycle. Its application is direct without composting. It was observed the practice of burying crop residues in the soil during plowing.

If the use of organic fertilizers is not widespread, the supply of mineral fertilizers is systematic in all sites. Urea, a mineral fertilizer composed mainly of nitrogen, is the main source of inorganic material used by market gardeners in vegetable production. Spreading on crops is in solid form (Figure 2c). All gardeners use at least once per cycle.
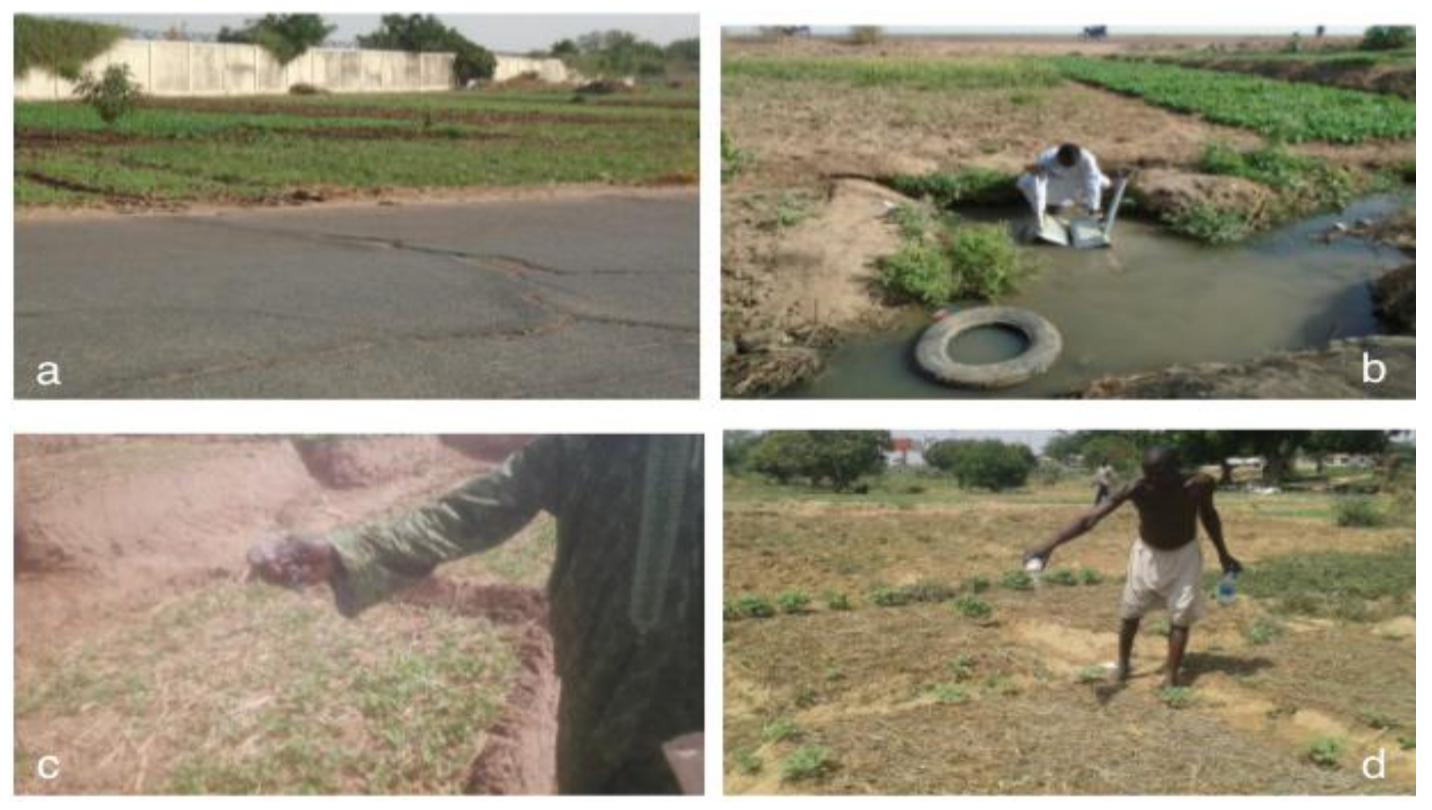

Figure 2. Diversity of health risks. Legend: a. Proximity of the road to Djamba Ngato-Airport; $b$. Use of wastewater at Djamba Ngato-Airport; c. Spreading Urea (Habena Double-way); d. Phytosanitary treatment with Perfect Killer (Habena Double-way) 


\subsubsection{Phytosanitary Protection of Crops}

Chemical control is the only method used by market gardeners in the study area. In order to meet growing demand and achieve economically viable production levels, market gardeners use several types of pesticides (Figure 3).

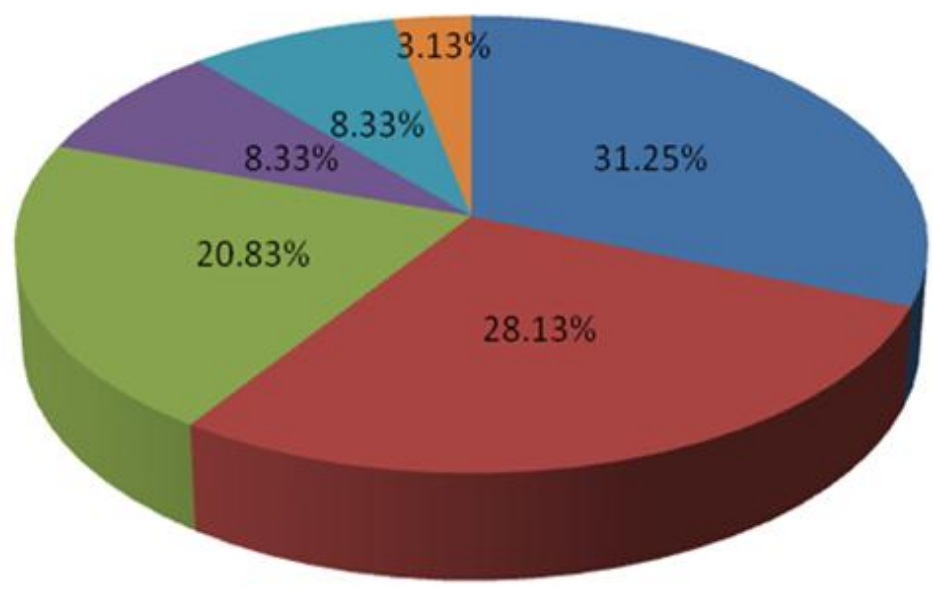

\section{Type of Pesticides}

= Perfect killer (I)

- Cypercal (I)

m CONQUEST (I)

- PENNCOZEB(F)

- Pacha (I)

= Optimal 20SP (I)

Figure 3. Phytosanitary products used in market gardening (I: Insecticide, F: Fungicide)

The insecticide (Perfect Killer; Cypercal; Conquest; Pacaha et Optimal 20 SP) are the pesticides used. However, Perfect Killer is the most represented pesticide $(\mathrm{P}<0.001)$, while the fungicide is only represented by Penncozeb 80 and is used by only $8.33 \%$ of producers located in Habena (difference not significant $x^{2}=3.2, \mathrm{ddl}=1 ; \mathrm{P}>0.05$ ). This study identified a single mode of use of these phytosanitary products in the production system: treatment by a hand-held sprayer (Figure 2d). It consists of dissolving the product with water inside a 1.51 bottle before starting the operation. The measure used to apply pesticides on farms is the bottle cap (two caps per 1.5L bottle). The number of applications per cycle varies according to the producers' experiences. The treatment is done whenever there are insects on the plant. Finally, the harvest is made without respect of the withdrawal period (the last treatment is made one to two weeks before the harvest of the vegetables).

\subsection{Harvest and Transport of Finished Products}

The harvest is the end of the cultivation period and the beginning of the preparation for the market. Fresh vegetables for market or own consumption are harvested by hand.

These freshly harvested vegetables are soaked in irrigation water before being packed in fully or partially closed bags. Transportation to the markets is done using motorcycles.

\subsection{Evaluation of the Microbiological Quality of Market Gardening Products}

Table 3 shows the prevalence of pathogens isolated in market garden products. Microbiological analysis of vegetables shows a high burden of pathogenic germs (Table 3). Lettuce and sorrel show high microbial loads with proportions of Escherichia coli and Salmonella spp. respectively $46.7 \%$ and $7 \%(\mathrm{x} 2=39.459, \mathrm{ddl}=1, \mathrm{p}=$ $0.001)$. 
Table 3. Prevalence of isolated pathogens in market garden produce

\begin{tabular}{llllll}
\hline \multirow{2}{*}{ Analyzed part } & $\begin{array}{l}\text { Market garden } \\
\text { products }\end{array}$ & \multicolumn{4}{l}{ Number of germs UFC/g per sample (\%) } \\
& E. coli & Aeromonas spp. & Salmonella sp. & S. aureus \\
\hline \multirow{5}{*}{ Leaf } & Lettuce & $7(46.7)$ & $2(13.3)$ & $1(7)$ & $3(20)$ \\
& Rocket & $1(7)$ & $0(0)$ & $0(0)$ & $0(0)$ \\
& Celery & $2(13.3)$ & $1(7)$ & $0(0)$ & $1(7)$ \\
& Parsley & $5(33.3)$ & $0(0)$ & $0(0)$ & $0(0)$ \\
& sorrel & $7(46.7)$ & $0(0)$ & $1(7)$ & $0(0)$ \\
\multirow{5}{*}{ Fruit } & Spinach & $1(7)$ & $0(0)$ & $0(0)$ & $0(0)$ \\
& Cabbage & $6(40)$ & $0(0)$ & $1(7)$ & $0(0)$ \\
\multirow{5}{*}{ Root / bulb } & Okra & $2(13.3)$ & $0(0)$ & $0(0)$ & $1(7)$ \\
& Green beans & $3(20)$ & $0(0)$ & $0(0)$ & $3(20)$ \\
& Green pepper & $2(13.3)$ & $0(0)$ & $0(0)$ & $2(13.3)$ \\
& Carrot & $3(20)$ & $0(0)$ & $0(0)$ & $3(20)$ \\
& Green onion & $3(20)$ & $0(0)$ & $0(0)$ & $5(33.3)$ \\
\hline
\end{tabular}

\section{Discussion}

The study made it possible to analyze, in all the selected production sites, the relevant risk factors that could lead to the appearance of microbiological and physicochemical hazards on fresh vegetables. These main factors identified, which could be at the source of the risks to human health, are grouped in three (3): the environment of the farms, the agricultural practices and finally the harvesting and the transport. This study first shows a variety of vegetables produced by market gardeners, dominated, on occasion, by lettuce and rocket. Depending on the organs consumed, market gardening is geared towards the production of leafy vegetables. The species cultivated for their leaves are the most represented compared to those cultivated for their fruit, root or bulb.

The results of our research conducted in five (5) vegetable production basins of the city of N'Djamena reveal that behaviours are not without consequences on the health of consumers. First, the proximity of roads is a source of contamination by heavy metals, pathogens, dust and impurities. With regard to irrigation, the origin, type and quality of water, the type of plant, the method of irrigation and the type of irrigation (measure of exposure of the edible part of the plant to water) and the period between the last irrigation and the harvest (possible disappearance of microorganisms for example by photodegradation, degradation by soil microorganisms, transformation by the plant, etc.) play an important role (Allende \& Monaghan, 2015; AFSCA, 2009; Uyttendaele et al., 2015). Three main risk factors related to irrigation water used in production basins in the study area were identified: water source, irrigation method and type of plants. The results of the investigation showed that the producers of the same production site use the same source of water. This is why in our study area, the health risks vary according to the geographical location of the production sites. Wastewater is known to be more susceptible to contamination by pathogens than groundwater and surface water. The reuse of partially or untreated wastewater in agriculture is widespread in African cities (Cissé et al., 2002) and according to FAO (2007), 200 million urban farmers worldwide would use wastewater, untreated or partially treated. The use for irrigation of sewage collected on the sewer system, exposes the production to health risks via certain metals and metalloids (copper, molybdenum, nickel, selenium, and zinc) which certainly are essential to the good plant growth, but are toxic at high concentrations. Qadir et al. (2000) found that in the case of irrigation with raw sewage, leafy vegetables accumulated certain metals such as cadmium in larger quantities than leafless vegetables. Sharma et al. (2007) concluded that sewage irrigation increased the contamination of the edible parts of vegetables by cadmium, lead and nickel, and that this poses long-term potential health risks. In addition to the risks they pose to consumers, the heavy metals they contain can also increase plant susceptibility to disease and pests, generally resulting in excessive pesticide use that is responsible for plant residues of pesticide residues in quantities greater than the acceptable limits. The risk of contamination of crops following sprinkler irrigation is also higher than the cases where a drip system is used. Our survey showed that all growers use sprinkler as their only irrigation method. On the other hand, the degree of risk is not the same from one culture to another. In fact, leafy vegetables do not carry the same risk as other types of vegetables. Pazou Yehouenou et al. (2010) reported in their study the presence of heavy metals and nitrates in vegetable crops at various concentrations. To intensify their productions, gardeners use a large amount of fertilizers. The overdose practices observed highlight the risks of over-fertilization nitrogen leading to a build-up of nitrates in the leaves of vegetables. This cannot remain without consequences on the health of consumers. Nitrates as such are not dangerous to health, but ingested by humans, they are degraded by a bacterium and turn into nitrites. Historically, nitrates and their derivatives have 
been implicated in the occurrence of acute intoxication, methemoglobinemia, in newborns and in the occurrence of long-term cancers, particularly digestive (Testud, 2004 ; Vilaginès, 2003). The use of pesticides reduces crop losses due to pests and stabilizes yields. However, their uncontrolled use can be a source of harm to human health and the environment (Kanda et al., 2014). The residues of pesticides inevitably constitute risks of poisoning in the short, medium or long term for humans (Mondedji et al., 2015). In our study area, a variety of pesticides are used inappropriately, and the harvesting of vegetables is done without respect of safety time. They leave, inevitably, residues that could harm the health of consumers. Other studies (Farag and al., 2011; Touré et al., 2015; Bakary et al., 2019) mentioned in their work the risks associated with the use of pesticides that can lead to metabolic diseases such as cancer. While the use of these products is often necessary for producers to achieve their production objectives, it is important to remember that pesticides are toxic and their use can only be accepted or encouraged if they are fully controlled. Use and risks to human health and the natural environment that may be affected (Devillers et al., 2005). Pesticide leaves, inevitably, residues that could harm human health and the environment. This mortgages the quality of vegetables because horticultural products must meet strict quality standards, particularly with regard to maximum pesticide residue limits. Integrated pest management reduces the number of chemical interventions and produces healthy foods that meet established standards (Colignon et al., 2000). Biopesticides could be an alternative to the misuse of synthetic pesticides. Among new crop protection technologies, the use of effective and less toxic botanical insecticides would be an alternative to the use of synthetic pesticides in the control of insect pests (Cloyd 2004; Charleston et al., 2005, Shannag and al., 2014). In terms of harvesting and transportation, there are four (4) potential risks that can affect the hygienic quality of finished products:

- Although this manual may occur during this stage, contamination due to poor hygiene.

- After cutting, the release of cellular liquids plant offers a favourable nutrient medium for the growth of microorganisms exposing consumers to possible danger.

- Rinse water from freshly harvested vegetables is also a potential source of pathogen contamination. If these agents survive on the products, they can threaten the health of the consumer and cause food poisoning.

- During transportation to urban markets, fresh vegetables may also be contaminated by lack of consistent packaging and unsuitable means of transport. This contamination can be physical as well as microbiological.

The results of the microbiological analyze show that the high levels of bacteria indicating fecal contamination coincide with the sites where the producers irrigate with the wastewater. Indeed, the site most loaded with pathogenic bacteria was that of Djamba Ngato where isolated bacterial species were isolated from the samples with a high contamination in proportion of E.coli and S. aureus. Other authors (Barro et al., 2007, Mayoré et al., 2018 ) indicated that $E$. coli is an indicator of faecal contamination. For $S$. aureus, this germ is commonly involved in food poisoning due to the production and their toxins are responsible for animal and human disease (Pereira et al., 2017). The presence of E. coli and S. aureus in vegetables is thought to be due to the unsanitary environment, the use of dirty water and the poor hygienic practices of the staff. Meldrum et al. (2016) in UK also isolated E. coli and S. aureus in samples of vegetables such as salads and in sauces used for the preparation of salads. Also, several authors (Baba-Moussa et al., 2006; Tidjani et al, 2016; Doutoum et al., 2019) have found these germs in food. The identification of these pathogens confirms the direct contamination of vegetables produced by irrigation sewage or by open defecation. In principle, the raw fruits are not likely to allow the growth of pathogenic microorganisms when they maintain the integrity of their envelope. But if they are poorly sorted, transported, stored in poor hygienic conditions and poorly cleaned, they constitute a source of microbial contamination (ACIA, 2012). Aeromonas spp. was found with a proportion of $13.33 \%$ in salads. The presence of these bacteria in the purified effluents, sometimes at concentrations higher than those of faecal coliforms, poses a problem of sanitary interest (Maalej et al., 2002). Vegetables are often watered by river water or effluents. For salmonella, they were found only in two vegetable samples. These results corroborate with those of Traore et al. (2015), who also identified salmonella in salads but with a high proportion (50\%).

\section{Preventive Measures}

In urban and peri-urban vegetable farms in the city of N'Djamena, the mechanisms by which vegetables may be contaminated are complex (Table 4). Their high-water content, the absence of a lethal process such as cooking to eliminate pathogenic microorganisms, also do not guarantee the sanitary quality of the vegetables produced and can thus increase the risk of intoxication. As a result, the prevention of contamination of vegetables by pathogenic microorganisms (Escherichia coli, Aeromonas hydrophila, Aeromonas sobria, Salmonella spp., Staphylococcus aureus) and residues of harmful chemicals (heavy metals), is the most effective way to ensure the safety of these products generally consumed raw. Several authors (Atolaye et al., 2007 ; Katemo Manda et al., 
2010 ; Djibrine et al., 2018) ) indicated that heavy metals are among the main pollutants in the environment, with a high potential for toxicity in animal species. Special precautions then deserve to be taken before the consumption of vegetables and fruits. The washing of vegetables and fruits with drinking water and their disinfection would be necessary to prevent food poisoning and protect the health of consumers. This can be accomplished by means of fundamental preventive approaches, such as good agricultural practices (reasoned fertilization, clean water, treated wastewater, approved phytosanitary products, among others.) and the implementation of the system HACCP (Hazard Analysis and Critical Control Point).

Table 4. Potential Risks of Contamination of Leafy Vegetables and Preventive Measures

\begin{tabular}{|c|c|c|}
\hline $\begin{array}{l}\text { Production } \\
\text { stage }\end{array}$ & Risks / Potential dangers & Prevention \\
\hline $\begin{array}{l}\text { Place of } \\
\text { production }\end{array}$ & $\begin{array}{l}\text { Eventual contamination by heavy metals, } \\
\text { pathogenic germs, dust and impurities due } \\
\text { to the proximity of roads. }\end{array}$ & $\begin{array}{ll}- & \text { Maintain the sites; } \\
- & \text { Set up a protection hedge. }\end{array}$ \\
\hline $\begin{array}{l}\text { Inorganic } \\
\text { fertilization }\end{array}$ & $\begin{array}{l}\text { Possibility of introduction of heavy metals } \\
\text { due to non-compliance with fertilizer use } \\
\text { requirements }\end{array}$ & $\begin{array}{l}\text { Determine the right quantity and the best } \\
\text { adapted product as well as the optimal date and } \\
\text { the good location of the input (reasoned } \\
\text { fertilization) }\end{array}$ \\
\hline Irrigation & $\begin{array}{l}\text { Possible contamination by pathogenic } \\
\text { microorganisms present in the water and } \\
\text { by the presence of heavy metals. }\end{array}$ & Treat sewage water \\
\hline $\begin{array}{l}\text { Phytosanitary } \\
\text { protection }\end{array}$ & $\begin{array}{l}\text { Application of unapproved products that } \\
\text { exceed the maximum pesticide residue } \\
\text { limit and pre-harvest timelines }\end{array}$ & $\begin{array}{l}\text { Use pesticides registered for cultivation; } \\
-\quad \text { Scrupulously respect the instructions for } \\
\text { use; } \\
-\quad \text { Respect the dosages of the active } \\
\text { ingredients and the deadlines before harvesting; } \\
- \text { Use biopesticide and integrated pest } \\
\text { management }\end{array}$ \\
\hline Harvest & $\begin{array}{l}\text { Introduction of } \quad \text { pathogenic } \\
\text { microorganisms attributable to unhealthy } \\
\text { producers or rinsing water; Wash hands } \\
\text { before harvest }\end{array}$ & $\begin{array}{l}\text { Rinse with fresh water fresh vegetables once } \\
\text { harvested }\end{array}$ \\
\hline Transport & $\begin{array}{l}\text { Contamination by } \quad \text { pathogenic } \\
\text { micro-organisms, chemicals and / or } \\
\text { foreign objects (sand, insects, plant debris, } \\
\text { stones, ...) }\end{array}$ & $\begin{array}{l}\text { Transport the products in transport vehicles and } \\
\text { containers intended to receive the products } \\
\text { Destroy vegetables with diseases, damaged ... }\end{array}$ \\
\hline
\end{tabular}

\section{Conclusion}

This study has made the possible to better understand the risk factors for microbiological and physicochemical hazards in the N'Djamena urban and peri-urban vegetable production chain and to draw the consequences for human health. The results show that the environment of the production basins, the current farming practices and the transport of fresh vegetables to markets contribute to the deterioration of the sanitary quality of the vegetables. In fact, practices of over-fertilization with mineral fertilizers, inappropriate or inappropriate use of plant protection products, the use of wastewater noted during the surveys, are not likely to guarantee the hygienic quality of the products resulting from the urban and peri-urban vegetable farms. The analysis of the microbiological quality of the fresh vegetables produced and fruits highlighted the presence of pathogenic microorganisms in the samples analyzed. The risks of intoxication of consumers are large and real. But the consumer has no way of detecting the presence of dangerous substances in food and it completely depends on the seriousness and responsibility of all members of the production and distribution chain. A combined action of different actors in urban agriculture is essential for sustainable food security in urban and peri-urban areas in the Sahelian zone such as N'Djamena. In perspective, it will be necessary to consider another study for in-depth knowledge of hazards in the production chain of vegetable crops.

\section{Acknowledgment}

The authors thank the producers of the market gardening sector who contributed to this study. 


\section{References}

ACIA, Agence Canadienne d'Inspection des Aliments. (2012). Code d'usages pour la production et la distribution de jus de pomme et de jus d'autres fruits non pasteurisés au Canada. pp. 11.

AFNOR (2002). Microbiologie alimentaire. Méthodes horizontales de référence. Tome 1 , 8 ème édition Saint Denis La Plaine, Recueil normes, Agroalimentaire, 299 p.

AFSCA. (2009). Qualité de l'eau d'irrigation en production primaire végétale et sécurité alimentaire (dossier Sci Com 2008/02: auto-saisine). Bruxelles: Agence fédérale pour la Sécurité de la Chaîne alimentaire (AFSCA). Retrieved from

http://www.favv-afsca.fgov.be/comitescientifique/avis/2009/_documents/AVIS28-2009_FR_DOSSIER2008 -02.pdf

Allende, A., \& Monaghan, J. (2015). Irrigation Water Quality for Leafy Crops: A Perspective of Risks and Potential Solutions. International Journal of Environmental Research and Public Health, 12(7), 7457-7477. https//doi.org/10.3390/ijerph120707457

Atolaye, B., \& Aremu, M. (2007). Bioaccumulation of some trace elements in the body parts of fish species associated with soil sediment and water from "Magani" confluence in Nasarawa State, Nigeria. Elect $J$ of Environ Agric Food Chem., 6(5), 2001-2008.

Baba-Moussa, L., Bokossa, Y. I., Baba-Moussa, F., Ahissou, H., ... Adeoti, Z. (2006). Etudes des possibilités de contamination des aliments de rue au Benin : Cas de la ville de Cotonou. J Rech Sci Univ Lomé (Togo), série A, 8, 149-156.

Bakary, T., Guira, F., Sourabié, P. B., Zongo, O., Tapsoba, F., Zongo, C., Drabo, K. M., Traoré, Y., \& Savadogo, A. (2019). Evaluation of heavy metals and pesticides contents in market-gardening products sold in some principal markets of ouagadougou (burkina faso). J Microbiol Biotech Food Sci., 8(4), 1026-1034. https://doi.org/10.15414/jmbfs.2019.8.4.1026-1034

Barro, N., Gamene, A. A., Itsiembou, Y., Savadogo, A., Nikiema, A. P., Outtara, C. A. T., de Souza, C. A., \& Traoré, A. S. (2007). Street-vended Food improvement : Contamination Mecanism and Application of Food Safety Objective Strategy : Critical review, Pakistan journal of nutrition, 6(1), 1-10. https://doi.org/10.3923/pjn.2007.1.10

Charleston, D. S., Kfir, R., Vet, L. E. M., \& Dicke, M. (2005). Behavioural responses of diamondback moth Plutella xylostella (Lepidoptera: Plutellidae) to extracts derived from Melia azedarach and Azadirachta indica. Bulletin of Entomological Research, 95(5), 457-465. https://doi.org/10.1079/BER2005377

Cissé, G., Kientga, M., Ouédraogo, B., \& Tanner, M. (2002). Développement du maraîchage autour des eaux de barrage à Ouagadougou: quels sont les risques sanitaires à prendre en compte? Cahiers d'études et de recherches francophones. Agricultures, 11(1), 31-38.

Colignon, P., Haubruge, E., Hastir, P., Gaspar, C., \& Francis, F. (2000). Effet de l'environnement proche sur la biodiversité entomologique en culture maraichères de plein champ. Parasitica, 56(2-3), 59-70.

Cloyd, R. A. (2004). Natural Instincts Are natural insecticides safer and better than conventional insecticides?. American Nurseryman, 200, 38-41.

Devillers, J., Farret R., Girardin, P., Rivière, J. L., \& Soulas G., (2005). Indicateurs pour évaluer les risques liés à l'utilisation des pesticides: Tec et Doc, Lavoisier. 278 p, 2-7430-0747-8.

Djibrine, A. O., Flibert, G., Tidjani, A., Rirabe, N., Patcha, M., Bakary, T., Abdoullahi, H. O., Traoré, Y., \& Savadogo, A. (2018). Risks Assessments of Heavy Metals Bioaccumulation in Water and Tilapia nilotica Fish from Maguite Island of Fitri Lake. Current Journal of Applied Science and Technology, 26(2), 1-9. https://doi.org/10.9734/CJAST/2018/39384

Doutoum, A. A., Tidjani, A., Nazal, A. M., Kimassoum, D., \& Bessimbaye, N. (2019). Microbiological Quality Assessment of the Main Food Consumed in Collective Catering in the City of N'Djamena-Chad. Trop Med Health: JTMH-139, 2019(01).

FAO. (2007). L'agriculture biologique peut contribuer à la lutte contre la faim, Rome, Italie. Retrieved from www.fao.org/newsroom/fr/news/2007

FAO/OMS. (2003). Garantir la sécurité sanitaire et la qualité des aliments: Directives pour le renforcement des systèmes nationaux de contrôle alimentaire. FAO/OMS Rome, Italie. 
Farag, R. S., Abdel-Latif, M. S., Abdel-Gawad, A. E., \& Dogheim, S. M. (2011). Monitoring of pesticide residues in some Egyptian herbs, fruits and vegetables. International Food Research Journal, 18, 659-665. https://doi.org/10.1080/02652030210157655

Golhor, K. (1995). L'agriculture urbaine en Afrique tropicale : évaluation in situ pour initiative régionale. Cities Feeding People Series, Report 14, pp. 27.

Kanda, M., Akpavi, S., Wala, K., Djaneye-Boundjou, G., \& Akpagana, K. (2014). Diversité des espèces cultivées et contraintes à la production en agriculture maraîchère au Togo. International Journal of Biological and Chemical Sciences, 8(1), 115-127. http://dx.doi.org/10.4314/ijbcs.v8i1.11

Katemo, M. B., Colinet, G., André, L., Chocha, M. A., Marquet, J. P., \& Micha, J. C. (. 2010). Evaluation de la contamination de la chaîne trophique par les éléments traces $(\mathrm{Cu}, \mathrm{Co}, \mathrm{Zn}, \mathrm{Pb}, \mathrm{Cd}, \mathrm{U}, \mathrm{V}$ et As) dans le bassin de la Lufira supérieure (Katanga/ RD Congo). Tropicultura, 28(4), 246-252.

Leyral, G., \& Vierling, E. (1991). Microbiologie et toxicologie des aliments. Hygiène et Sécurité Alimentaire, $3^{\text {ème }}$ édition, Science des aliments. Collection doin, Cndp, Aquitaine, pp. 223-224.

Maalej, S., Mahjoubi, A., Kammoun, A., \& Bakhrouf-Fadhila, A. (2002). Les Aeromonas mobiles : quelle évolution spatiale et temporelle dans un effluent urbain et en milieu marin côtier?. Revue des sciences de l'eau, 15(1), 273-287. https://doi.org/10.7202/705452ar

Mayoré, A. D., Tidjani, A., Bessimbaye, N., Asséta, K., Kuan, A. T., René, D., Bagré, T. S., \& Barro, N. (2017). Characteristics of the Street Food Sector in N'Djamena, Chad. Food Science and Nutrition Technology, 2(3), 000123. https://doi.org/10.23880/FSNT-16000123

Meldrum, R. J., Smith, R. M. M., Ellis, P., \& Garside, J. (2016). Microbiological quality of randomly selected ready-to-eat foods sampled between 2003 and 2005 in Wales, UK. International Journal of Food Microbiology, 108, 397-400.

Milleville, P. (1987). Recherche sur les pratiques des agriculteurs, dans: Cahiers de la recherche-développement: Numéro, 16, 7.

Mondedji, A. D., Nyamador, W. S., Amevoin, K., Adéoti, R., Abbévi, A. G., Koffivi, K. G., \& Glitho, I. A. (2015). Analyse de quelques aspects du système de production légumière et perception des producteurs de l'utilisation d'extraits botaniques dans la gestion des insectes ravageurs des cultures maraîchères au Sud du Togo. Int. J. Biol. Chem. Sci., 9(1), 98-10. http://dx.doi.org/10.4314/ijbcs.v8i1.11

Moustier, P. (1990). Dynamique du maraîchage Périurbaine en Afrique Subsaharienne. Etude de cas pour un meilleur diagnostic de l'approvisionnement vivrier des centres urbains. CIRAD/IRAT/Labo Agro-eco, 8, 1990.

Nazal, A. M., Tidjani, A., Doudoua, Y., \& Balla, A. (2017). Le Maraichage en milieu urbain et périurbain: cas de la ville de N'Djamena au Tchad. JUNCO|, Journal of Universities and International Development Cooperation, 1 .

Pazou, Y. E. A., Soton, A., Azocli, D., Acakpo, H., Boco, M., Fourn, L., Houinsa, D. (2010). Contamination du sol, de l'eau et des produits maraîchers par des substances toxiques et des métaux lourds sur le site de Houéyiho (Cotonou) en République du Bénin. Int. J. Biol. Chem. Sci., 4(6), 2160-2168. https://doi.org/10.4314/ijbcs.v4i6.64951

Pereira, L. S., Machado, R. Z., Lopes, J. B. A., Carvalho, I. A., \& Costa, F. N. (2017). Toxigenic Staphylococcus aureus in processing of coalho and mozzarella cheese. African Journal of Microbiology Research, 11(13), 521-529. https://doi.org/10.5897/AJMR2017.8482

Qadir, M., Ghafoor, A., Murtaza, G., \& Murtaza, G. (2000). Cadmium concentration in vegetables grown on urban soils irrigated with untreated municipal sewage. Environment, Development and Sustainability, 2(1), 11-19. https://doi.org/10.1023/A:1010061711331

Shannag, H. S., Capinera, J. L., \& Freihat, N. M. (2014). Efficacy of different neem-based biopesticides against green peach aphid, Myzus persicae (Hemiptera: Aphididae). International Journal of Agricultural Policy and Research, 2(2), 061-068. http://dx.doi.org/10.15739/IJAPR.014.

Sharma, R. K., Agrawal, M., \& Marshall, F. (2007). Heavy metal contamination of soil and vegetables in suburban areas of Varanasi, India. Ecotoxicology and environmental safety, 66(2), 258-266.

https://doi.org/10.1016/j.ecoenv.2005.11.007

Smith, O. B., Moustier, P., Mougeot, L. J., \& Fall, A. (2004). Développement durable de l'agriculture urbaine en 
Afrique francophone: enjeux, concepts et méthodes. CRDI, Ottawa, ON, CA.

Temple, L., \& Moustier, P. (2004). Les fonctions et contraintes de l'agriculture urbaine dans quelques villes africaines (Yaoundé, Cotonou, Dakar). Cahiers Agricultures 2004, 13(1), 15-22.

Testud, F. (2004). Engrais minéraux. EMC Toxicologie Pathologie, 1(1), 21-28. https://doi.org/10.1016/j.emctp.2003.10.002

Tidjani, A., Bechir, M., Moussa, A., Dionadji, M., \& Mbairi, D. G. (2016). Food on the street: Experience of the Research and Support Project for Food Safety of the Street (PRASAR) in Chad. - Special Series - National Forum on Nutrition and Food. Scientific Review of Chad, 75-86.

Touré, N. K. P., Yoboue, K. E., \& Yao-Kouame, A. (2015). Evaluation of the heavy metals traces, pesticides and plasticizers in the products maraichers (gombo, corete potagere, epinard and aubergine) in lavallee of the nieki, south-east of the Côte.d'ivoire. European Scientific Newspaper, 11, 33, 14.

Traoré, O., Nyholm, O., Sitonen, A., Bonkoungou, I. J. O., Traoré, A. S., Barro, N., \& Haukka, K. (2015). Prevalence and diversity of salmonella enterica in water, fish and lettuce in Ouagadougou, Burkina Faso. BMC Microbiology, 15-151. https://doi.org/10.1186/s12866-015-0484-7

UNDP. (1996). Urban agriculture: Food, jobs and sustainable cities. New York, États-Unis, UNDP, 1996, 302.

Uyttendaele, M., Jaykus, L. A., Amoah, P., Chiodini, A., Cunliffe, D., Jacxsens, L., \& Medema, G. (2015). Microbial hazards in irrigation water: Standards, norms, and testing to manage use of water in fresh produce primary production. Comprehensive Reviews in Food Science and Food Safety, 14(4), 336-356. https://doi.org/10.1111/1541-4337.12133

Vilaginès, R. (2003). Eau, Environnement et santé publique. Introduction à l'hydrologie. Éditions Tec \& Doc: 2ème éd., pp. 109.

\section{Copyrights}

Copyright for this article is retained by the author(s), with first publication rights granted to the journal.

This is an open-access article distributed under the terms and conditions of the Creative Commons Attribution license (http://creativecommons.org/licenses/by/4.0/). 